\title{
8
}
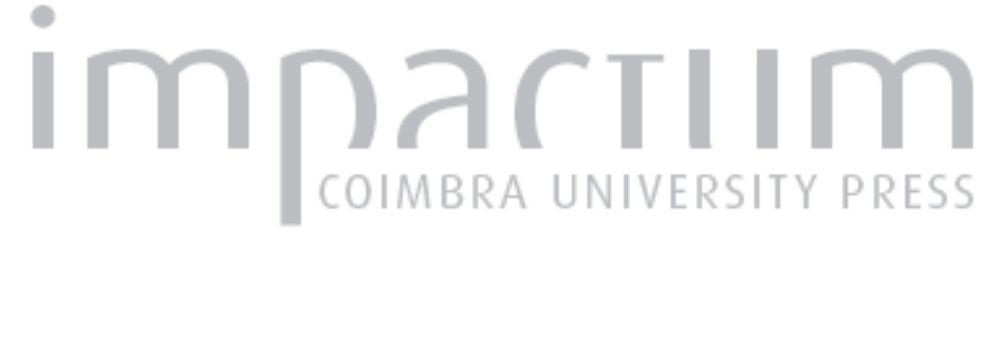

\section{Logic(s) of subjection: Butler's symptomatic reading of Hegel and Lacan on the symbolic}

Autor(es): $\quad$ Carvalho, Cláudio Alexandre S.

Publicado por: Faculdade de Letras da Universidade de Coimbra, Instituto de Estudos

URL

persistente: Filosóficos

DOI: DOI:http://dx.doi.org/10.14195/0872-0851_34_8

Accessed : $\quad$ 26-Apr-2023 07:19:16

A navegação consulta e descarregamento dos títulos inseridos nas Bibliotecas Digitais UC Digitalis, UC Pombalina e UC Impactum, pressupõem a aceitação plena e sem reservas dos Termos e Condições de Uso destas Bibliotecas Digitais, disponíveis em https://digitalis.uc.pt/pt-pt/termos.

Conforme exposto nos referidos Termos e Condições de Uso, o descarregamento de títulos de acesso restrito requer uma licença válida de autorização devendo o utilizador aceder ao(s) documento(s) a partir de um endereço de IP da instituição detentora da supramencionada licença.

Ao utilizador é apenas permitido o descarregamento para uso pessoal, pelo que o emprego do(s) título(s) descarregado(s) para outro fim, designadamente comercial, carece de autorização do respetivo autor ou editor da obra.

Na medida em que todas as obras da UC Digitalis se encontram protegidas pelo Código do Direito de Autor e Direitos Conexos e demais legislação aplicável, toda a cópia, parcial ou total, deste documento, nos casos em que é legalmente admitida, deverá conter ou fazer-se acompanhar por este aviso. 


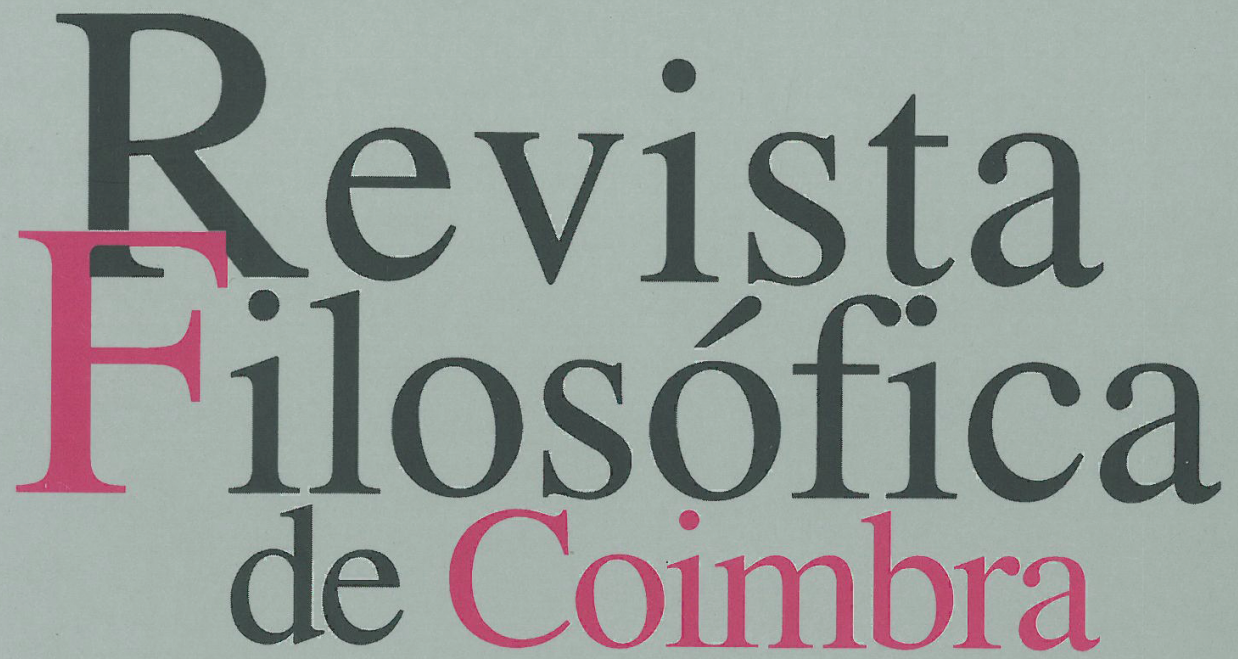

vol.17 | n.34 | 2008

José Reis

Manuel Moreira da Silva Helder Gomes

Filipe P. S. M. Menezes Edmundo Balsemão Maria João Silveirinha Luís António Umbelino Cláudio Alexandre S. Carvalho Armindo dos Santos Ana Isabel Boura Regina Queiroz Dulce Morgado Neves 


\title{
LOGIC(S) OF SUBJECTION. BUTLER'S SYMPTOMATIC READING OF HEGEL AND LACAN ON THE SYMBOLIC ${ }^{1}$
}

\author{
CLÁUDIO ALEXANDRE S. CARVALHO \\ (Unidade I \& D - L.I.F. - Linguagem, Interpretação e Filosofia, \\ Faculdade de Letras da Universidade de Coimbra)
}

\section{Summary}

The aim of this paper is to present you the way by which, in the construction of her theory of gender and subjection, Judith Butler maintained as crucial references of "critical support", the works of Hegel and J. Lacan and their respective placements of Sittlichkeit ${ }^{2}$ and symbolic.

We must acknowledge first that in Butler's work the predominant effort is mainly concerned with an attempt to plea against a universal model of subjection or resistance ${ }^{3}$, throughout her different books she never ceases to affirm that any logic of subjection and emancipation, in order to avoid the risk of misappropriation, must be conceived as

${ }^{1}$ With the exception of some minor changes, this text conforms to the one that supported my reading in the colloquium in 24 of June 2008. I want to present my gratitude to Dr. Laura Werner for her pleasant comments; they have helped me in clarify the purposes of this article.

2 Taken by Butler as «the shared set of [changeable] norms, conventions and values that constitute the cultural horizon in which subject emerges into self-consciousness (...)» (Butler, 2000 b:172).

${ }^{3}$ In this Butler's reiterated critiques to forms of feminism that remaining "stubbornly" attached to oppressive norms claimed in name of a putative identity of femininity for instance. In Lacanian legacy we encounter Julia Kristeva's theorization of the platonic chora as the disruptive identity placed in the outside, other of the symbolic order. Against this kind of identitarian politics, in its essentialists or "diaphanous"modes, Butler advances a rational critique of the very terms used in the construction of the fiction of identity and the norms attached with it. But Butler asserts that criticism is not enough given the dependence of one's existence in the normative sanctioned terms. (Cf. Butler, 1997: 129). 
historical and culturally variable. However, I sustain that there is a certain sense in which we can talk about logic (in the singular) in Butler's work; such meaning is to be found related to the experience of melancholia. In this experience we can locate the origin of the trouble consisting loosely on the discontinuity and contingent coupling between the imaginary (in which we can circumscribe the relation of oneself with its own body) and the level of social interaction (functioning according to symbolic efficacy) which entails the inevitability of gender ascriptions.

Before proceed I must prevent the reader -given its relevance to the understanding of individuation in Hegel and Lacan- that in this paper I will not address with the required attention, a topic that despite some controversy in academic debates, constituted a groundbreaking reading of classical tragedy and its conception of the feminine. I'm referring to Butler's critique of the indicative interpretations of Sophocles' play Antigone by both Hegel and Lacan.

In the following section I begin with a brief excursus over the presences of both authors in some of Butler's main theses concerning ontogenesis and gender ascription. Although circumscribed to Butler's work, this trail will display some theoretical affinities between the German philosopher and the French regenerator of psychoanalysis.

\section{Re-turning to the Hegelian theory of recognition}

A first glimpse to the way Butler reads and relates both authors is already presented in her doctoral thesis where she goes through the reception of the Hegelian oeuvre in Parisian intellectual circles since A. Kojève seminars, focusing mostly on the of the enormous impact of the Phenomenology of Spirit. In the re-edition of Subjects of Desire in 1999 we are offered an account of the way Lacan reinvented the Freudian legacy, escaping the so-called ego-psychology and the "biologism" that pervades Freudian Work, through recourse to the negativity characterizing the Hegelian subject. Nevertheless Lacan, as noted by Butler, always maintained a wavering position towards $\mathrm{Hegel}^{4}$. Along his career, the

${ }^{4}$ See mainly "Lacan: The Opacity of Desire"in Butler's Subjects of desire: Hegelian reflections in twentieth-century France (1987/1999: 186-204). In the "Subversion of the Subject" but also in Seminar XVII, Lacan defended that if we are «condemned to understand the ego, from beginning to end, in the movement of progressive alienation where self-consciousness places itself in Hegel's Phenomenology» (1966: 374), this «sliding movement [glissement] by which the Bewusstsein enables the covering of the confusion of the Selbst, comes precisely to show, in the Phenomenology of Spirit, by Hegel's precision, the reason of his mistake.» (1966 b: 170). 
French theorist have occasionally obliterated the errors of the a "traveller" in despair and the comedic character of the dialectic inversions in the Hegelian text, the constant shifts of the "for-itself"; in Butler's own words, how «this subject constantly misidentifies the Absolute in much the same way that the Lacanian subject of desire remains lured by an everelusive jouissance.» (Butler, 1987/1999: 196).

Butler underlines how Lacan, transposing the Hegelian subject to the subject of the signifier, will delineate individuation in a reinvention of Oedipus complex where Castration, always involving the imaginary threat of murder, preceding the access to language and metonymic displacement $^{5}$, is presented with similar traces to the reappearances of the terror of Absolute Master in the Phenomenology. This is the basic schema of forclusion (Verwerfung) that accordingly to Butler is instantiated in the theoretical construction of the "Law of the Father" determination of kinship and forms of desire.

Her critique falls also upon the division, generally propelled among Lacanians, between contingent/historical "sociality" and the transcendental domain of invariant symbolic structures conditioning the social (the Law), which is depicted by Butler as a rhetorical force resulting from a hasty reification of social codes. In her view this tendency has clear roots in what was once called Structuralism ${ }^{7}$.

In Gender Trouble and all subsequent works, related to how the body "comes to matter", the quest of Butler will be to reveal what is really covered by this forclusion, namely what she there designates has the "heterosexual matrix of desire", dictating from the outset that the subject is inserted in the system of signification where it becomes a discrete "I" submitted to a set of "identificatory" rules whose necessity derives solely from the norm itself. Incest taboo, theorized by Lévi-Strauss as a cultural fantasy, is the cornerstone that sustains such a Law (Cf. Butler, 1990/ 1999: $50 \mathrm{ff}$.) conceived as universal law with an autonomous "symbolic

5 This cardinal point of Lacan's theory, the original loss as condition of signification, is referred in different occasions by Butler (e.g.1990/1999: 55 and 1993: 70). In its infinite displacement the subject cannot accede to satisfaction (a final or adequate fulfillment of desire), only making the surrounding of a constitutive void, so that in the drive, the aim to the object (goal) becomes paradoxically the proper goal. (Lacan, 1973: 162-165).

6 «The law reasserts and individuates itself within the terms of every infantile entranced into culture» (Butler, 1990/1999: 55).

${ }^{7}$ According to Butler this designation conforms to every theory of culture in which the difference between Signifier and Signified is annihilated as an arbitrary relation and used in order to ground a (linguistic) system that controls the distribution of identity and lack. (Cf. e.g. Butler 1990/1999: 51 ff.) 
efficacy" . In Butler's view, this discursive strategy of domination resulting in binary distinctions, proceeds from the "projection" of a incestuous heterosexuality as the "pre-artificial" matrix of desire. Symbolic efficacy in accordance to the analysis Lévi-Strauss manifests the autonomy of the symbol towards the individual's psyche and the contingency of the "given", presiding to the mode by which the subject "transfers" to its own eroticization prescriptions derived from the law of the father without recourse to an unmediated truth about its own nature?

It is curious how Butler analogizes this clear ascendency in Lacan's concept of Symbolic, in a reading that recalls Beauvoir's interpretation of sexual difference drawing on the Lordship and Bondage dialectics, she considers the Lacanian pre-ontological positions grounding the symbolic -"being" and "having" the Phallus- as comparable to the positions of slave and master and the respective differential structure of recognition established as the outcome of the life and death struggle ${ }^{10}$. According to Butler this binary disjunction "suturing" the lack imposed by forclusion, holds an imaginary structure where women are taken to be a "function of men", i.e. are supposed to provide a full recognition demanded by men's autonomy, while at the same time, they represent the promise of des-individuating Jouissance. No wonder then that in the text that supports Butler's critique, The Signification of the Phallus, Lacan -unable to foresee his latter theory of feminine Jouissance- affirms that (invariably) women reject part of their femininity in striving for desire ${ }^{11}$.

Till this point Judith Butler didn't bring anything new (at least to Feminism); the crucial transition happens when, considering the involved double renunciation/loss of objectal cathexis in the melancholic formation

${ }^{8}$ Based mainly in the Works of the anthropologists such as David Schneider, Butler disclaim what she considers conjectural narrative imposed through deduction from the point of view of an universal structure of cultures. In the Lévi-straussian scheme of cultural intelligibility women as objects of patronymic exchange are equatable to words that following Butler,we could say, maintain a «intercourse between clans of men» (Butler, 1990/1999: 50).

${ }^{9}$ Working on the remote relation between analytic and shamanic cure Lévi-Strauss showed how the myth combines dispersed elements in a symbolic structure whose effectiveness is evidenced in the processes of transference (Cf. ID., 1949).

${ }_{10}$ Butler also notes that that interdependent positioning of "sexes" «recalls the Hegelian structure of failed reciprocity between master and slave, in particular the unexpected dependency of the master on the slave in order to establish his own identity through reflection.» (Butler, 1990/1999: 57).

11 «It is in order to be the phallus, i.e. the signifier of Other's desire, that the woman comes to reject an essential part of femininity, namely all her attributes' in the masquerade» (Lacan, 1966: 694). 
of the feminine ego, and Rivière's theory of the masquerade, she rejects the positive program to uncover a supposed authentic femininity prior to the mimicry. Dispositions are not primarily psychic facts but effects of cultural Law of intelligibility: originating social recognition or repudiation of "abjected" forms 12 . These norms, as it becomes clear in Butler's reading of Antigone are to be conceived as series of "normativazing" injunctions stabilizing the threshold of the symbolic in its connection with "virtuality" of death (the menaces of psychoses, abjection and unlivability), the necessary outside of kinship structures and melancholic subjects ${ }^{13}$.

Thus, the subject is this negative formed on a defining exclusion and repeated repressions. Butler acknowledges that the paradox of subjectivation (assujetissement) consists precisely in the fact that »the subject who would resist such norms is itself enabled, if not produced, by such norms (Butler, 1993: 15). In Bodies That Matter Butler emphasized that the iterative reproduction of the Law can not only consolidate its ontological status (juridical/normative), but also inadvertently creates the very possibility of its displacement ${ }^{14}$. Such a possibility is inherent to the norm itself, to its demand to be performed. In order to preserve its effectiveness the norm requires constant repetitions. This practice of citation always involves the spectre of "wrong" or "incomplete" actualizing of the law by its subjected subject. In other words, any signifier of identity is vulnerable to catachresis.

Butler insists that something remains always excluded from the very possibility of reiteration in the constant reconfiguration of the borders of Law. Here a certain Hegelian ground is taken by Butler as valuable. Butler

12 In Lacan's theory, pudency (pudeur), and it's general form shame, appears as the mean by which all the uncertainty surrounding one self's sexual experience comes to be "organized" through the process of individual defence against the spectre of the Other's punishment (1966: 662). The symbolic production of shame activated in a "irreflected" automatism can be said the most prominent indication of the subject as barred, "subject of the signifier" split from an (always mythical) vital substance.

${ }^{13}$ Butler differs with some feminist praising the reading of heroine's second death in Seminar VII: «One might expect that the turn to Lacan would usher in a more nuanced and promising consideration of the unconscious, but I would like to suggest that his reading also relocates Antigone's fatality in terms of the necessary limits of kinship. The law that mandates her unlivability is not one that might profitably be broken. And if Hegel comes to stand for the law of the state, Lacan deploys Antigone's apparent perversion to confirm an intractable law of kinship.» (2000: 40).

${ }^{14}$ After pointing the lure of a solid ground escaping infinite deferral Butler states: 'The subordination of the citation to its origin is thus a ruse, a dissimulation whereby the prior authority proves to be derived from the contemporary instance of its citation.(...) In this sense, then, the instance produces the fiction of the priority of sexed positions.» (1993: 109). 
dismisses the "idealism" of liberal trends frequently involved in political struggle and philosophical debate; it is not possible a structure of recognition all inclusive, in fact, foreclosure is constitutive, and identity is always in risk of the spectre of its own destabilization. Recurring to Hegel, she remarks that the philosopher does not strive to an all inclusive universality but presents a view of universality that assumes to be grounded in negations: «the assimilation of the particular into the universal leaves its trace, an inassimilable remainder, which renders universality ghostly to itself.» (Butler, 2000 a: 24)

In Contingency, Hegemony, Universality co-edited with E. Laclau and S. Žižek, after a brief passage through the critique of Kantian "Abstract Universality" advanced by Hegel in the opening sections of the Encyclopaedia of Philosophical Sciences ${ }^{15}$ considering the functioning of recognition and the possibility of cultural translation, Butler points to the ideological obfuscation supported in the recourse to the rhetorical distinction of form-content. According to Butler the Lacanian distinction between structural and political/historical levels is used to tacitly veil effective relations of power in the name of a supposed universality incapable to recognize its own parochialism (e.g. 2000 a: 35). The target of Butler's critique is the way those two Lacanian authors deal with contingency persistently taking the transcendental character of sexual difference as condition of intelligibility of culture. She states that this «kind of formalism (...) [is generated] by a process of abstraction that is never fully free from the remainder of the content it refuses.» (Butler, 2000: 144). Butler sustains that this kind of procedure, oscillating between the unsymbolizable character of the law and the retroactive reading of its instantiations, conforms perfectly to what Hegel had intended in his critique of "abstract universality", precisely the anti-philosophical effort of taking examples to illustrate an already accomplished truth. In her theorization of performativity, the American philosopher refuses the distinction between structural and cultural accounts, precisely by pointing to the fact that the positing function of language creates the illusion of substantiality, a core gendered self emanating from a prior substance. In this sense, and recognizing the situated cultural syntactic staging of subjectivation, we can only restate the importance of universal claims in recurring to the laborious practice of cultural translation ${ }^{16}$.

15 see Hegel (1999), Enzyclopädie der Philosophischen Wissenschaften im Grundrisse (1830), §§ 19-83: 61-120.

${ }^{16}$ Emphasising this point Butler recalls the transition from "Reason" to "Spirit" in Phenomenology of Spirit, there recognition is not possible outside the customary practices escaping to the sheer terror of Understanding (Cf. 2000 a: 20-25). 
In Butler's account,-Phenomenology operates according to a temporality irreducible to teleology which ends not in State ${ }^{17}$ or in the revelation of idea, but in the possibility of beginning, gesture towards infinity. She sustains that if we are to return to the Hegelian theory of recognition there we must capture, specially taking as point of departure the pilgrimage of Phenomenology, not stable and self-transparent subject but precisely a firm comprehension of its negativity ${ }^{18}$, its insertion in symbolic structures. In this reconsideration we must go beyond the theorization of Kojève, albeit showing the weight of Christian legacy in Hegelian work patented specially in the infinitude of subjective freedom exceeding history, in his "negative ontology" of desire Kojève remained anthropocentrically naïve sustaining a humanizing dialectic. The subject emerging under the different names: consciousness, self-consciousness, Spirit, Reason, discovers that the name must be sacrificed to take into account the conditions of its emergence (2000 b: 172-73). For Butler, the name must be released from any essentialist or descriptivist theory of identity and inserted in effective discursive strategies. The co-presupposed oppositions part of the Hegelian dialectic process lead to a crisis and nomination becomes equivocal "meaning everything and nothing" (2000 b: 174). No matter how complex the institution of the naming process is, it cannot imprison the subject under its designation, there is always something that remains unnameable. The failure of interpellation to attain its object detains the possibility of contested meaning. But this ideological failure relates not only to the possible re-composition of imaginary identifications and discursive re-significations, but also to the fact that something is excluded from the social identity and in fact constitutes, not secret detained by the subject, but a secret to the subject itself. In accordance to this view, recently in her theory Butler developed an ethical imperative that commands the suspension of the demand for self-identity disposed as a simple and stable "given". Is precisely on the basis of an

${ }^{17}$ In "Competing Universalities", Butler defends that even the predominant role assigned to the State in Philosophy of Right is conditioned by its relation to the other spheres of society and she emphasizes that the "Sittliche Welt" has its grounding in a extra-legal network of cultural values and norms. (2000 b: 175).

18 Butler didn't always sustained this reasoned interpretation of Hegel's theoretical value, in some works previous to Dialogues on The Left there have been various occasions in which she proffered things like: «The ideal of transforming all excluded identifications into inclusive features -of appropriating all difference into unity- would mark the return to a Hegelian synthesis which has no exterior and that, in appropriating all difference as exemplary features of itself, becomes a figure for imperialism, a figure that installs itself by way of a romantic, insidious, and all-consuming humanism.» (1993: 116). 
irrecoverable loss that Butler rejects the possibility of a coherent account of oneself, a (always) retrospective narration of myself that would exhaust my truth as an individual (e.g., 2005, $41 \mathrm{ff}$.).

Before proceed, I must make a remark that is to be taken as a "supplement". As we have been seeing, the operative ground of Butler's theory of gender is not the category of identity as a given but precisely the idea of an inherent instability of the mechanisms of subject's self-identification in interface with the symbolic frame of social construction of gender. In Butler's view Psychoanalysis can be taken as example of a theoretical and clinical discourse supporting stagnation and reassertion of heteronormative expectations. However we can't help to point an undeniable interpretative limitation, in her highly selective reading of Lacan, she centres almost exclusively in texts from the 50's, the beginning of a powerful system of thought whose formal propensity will not refuse contingency. Butler seems to discredit the philosophical audacity of Lacan which consisted precisely in maintaining the relative autonomy and coupling of the different levels: imaginary autonomy and social communication processes. Particularly in Gender Trouble Butler seems unable to see is the fact that the privilege of the Phallus as primary signific, binary indexing two impossible positions, is related to the assertion of distinct orders, the time of the particular individual (biographical time) and the symbolic order (endless generation of forms) always open to proliferative re-signification. In fact Butler recognizes the value of Psychoanalysis and is right to endorse a kind of obstinacy in the theorization of sexual difference guided by political agendas. But from a "disengaged" Lacanian standpoint it is important to underline that the chain of the signifiers (transient order of causality) is actualized by contingent action and temporal choices; in Žižek's interpretation of the pas tout logic for instance, is the "rock of the real", resisting and compelling symbolization, that enables a subjective interruption of causality and symbolic order through the recodification at imaginary and agency levels, always resulting from the relation to "desire as cause".

\section{Logic of subjection}

In the course of Butler's literary production Psychic Life of Power may be present as a singular text where recognizing the existence of insufficiencies in the Foucaultian account of "assujetissement", works the relation between at least three different systemic orders: the psychic, the body and the social: she states that: «A redescription of the domain of psychic subjection is needed to make clear how social power produces modes of reflexivity at the same time that it limits forms of sociality.» 
(1997: 21). Butler is opposing some tendencies, presented in what she qualifies as "sociologism", to erase the contingent linking between "exterior" forms of power and its psychic life.

I proceed with a brief circumscription of what we may understand by subjection in Butler's work relying on an essay that, in an inventive approach, took once again Hegel's Phenomenology as an inexhaustible ground for thinking the formation of the subject ${ }^{19}$. Butler followed the outcome of the famous section of Master and Slave dialectics, "Stoicism, Scepticism, and the Unhappy Consciousness" in order to answer the question "is there a structure of subjection?" (1997: 33). Putting it bluntly, this structure refers to the invariant mode by which in order to become, the subject must reinvest its own "energy" (the Hegelian Begierde, nietzschean Will, Freud's Instinct) against itself. Something that might helps us to think how one comes to submit to pernicious norms and ideals, not coercively imposed, but resulting from what Butler, following Hegel in the transition to the Unhappy Consciousness, calls: stubborn [Eigensionnigkeit] attachments.

In her critic reading of that section of Phenomenology she stresses that the body must be foreclosed in the transition to Spirit ${ }^{20}$. Butler's thesis is that in some way Hegel anticipates Freud's melancholic production of psychic topography and "bodily surface"; she states that: «the logic of subjection in both Hegel and Freud implies that the instrument of suppression becomes the new structure and aim of desire, at least when subjection proves effective» (1997: 60).

Melancholia, defined as the «untreatable remain in the limit of subjectivation» (1997: 29), points precisely to the incomplete character of a theory based exclusively on the focus of enunciation and social interaction. When the subject of the signifier takes language as a key to its self-interpretation, it is always already outside of what conditioned its coming to signification: the «unspeakability that organizes the field of the speakable (1997: 186)».

19 I refer to the essay first published in 1995 "Stubborn Attachment, Bodily subjection: Rereading Hegel on the Unhappy Consciousness" latter revised and included in Psychic Life of Power (1997: 30-62).

$20 \ll(\ldots)$ appears to be nothing other than a threat to the project of safety and selfsufficiency that governs the Phenomenology's trajectory.» (1997: 54). We see that Butler hurriedly devaluates the way in which formation is grounded in the experience of the body, and forgets the re-emergence of trauma and the various menaces of Spirit arising later in the text, but her main thesis must be taken into account. 
Butler returns and deepens theses concerning melancholia firstly advanced in Gender Trouble and reworked in Bodies That Matter ${ }^{21}$, bringing into relief specially the Freudian Corpus where we find the «traces of a history of enforced sexual prohibitions which is untold and which the prohibitions seek to render untellable» (1990/1999: 82). Melancholia, contrary to non pathological mourning, is the refusal in accept the object -already effectively- lost as lost. This suspension of the verdict of "reality" inaugurates the ego; this incorporates the ambivalence presented in the relation of the infans with the lost object, and will determine the way the body becomes invested with desire. Negative narcissism (and all its symptoms of self-accusation and self-beratement) is originated in this process in which a part of the ego has been unconsciously incorporated as lost, but, according to Butler, this doesn't derives simply from the structural condition that the ego is a poor substitute to the lost object ${ }^{22}$.

Butler notes that Freud doesn't stay properly restricted in "psychogenesis" but thinks topography, the division between ego and critical agency, in osmosis with social metaphors (1997: 178). And is this same reason that makes Butler discard Melanie Klein's theses as derived from an illusion of topology (Cf. 1997: 171). "Negation of negation" is the way the subject deals and tends to resolve the primordial experience of lack. This indicts the refusal of the possibility of certain kinds of attachments and has its origin in a "bissexualization of the psyche" (1997: 164). In accordance with the subtle shift from Mourning and Melancholia to The Ego and the Id, this "resolution" refers to the displacement of libido from object cathexis, the "disattached" libido reverses against ego itself turning it into a harbour of self-aggression. This occurs under ego's critical agency demanded by the Super-ego in order that the individual conforms to social expectations. Butler is peremptory in asserting that the ego-ideal to which Super-ego compares the ego is a social ideal of rectitude (Cf. 1997: 141). The "afterlife" of desire is placed on the prohibition, and super-egoic demands become the new site of investment.

21 Taking a closer look to the Lacanian formulations presented at the first Seminars, see specially chapter II of Bodies That Matter: "The Lesbian Phallus and the Morphological Imaginary", (1993: 51-93).

22 This accordingly to the famous dictum: in «mourning it is the world which has become poor and empty; in melancholia it is the ego itself» (Freud, 1917: 254). 
In oneself's account the access to what is prior to the order of communication is foreclosed, and irremediably nachträglich ${ }^{23}$. In Lacan's words «Jouissance is prohibited to who speaks as such, or still can be said only between the lines of whom is subject of the law, because the law is grounded on the prohibition itself» (1966 b: 184). Only afterwards can it make sense to present a certain stability of identity, a "core", resulting from the making of that interior topography, always indirectly related with what comes to be recognized as a woman or a man. The strict reduction of gender to its literalization is certainly a mistake, there is something out of the "script", something that according to Butler re-emerges, or more precisely returns, reinforcing gender performativity through abjection and repudiation. Butler rightly points that although melancholia is hetero and homosexual, the cultural codes tend to reinforce different rituals and activate some mechanisms operating in order to safeguard heterosexual melancholia. The subject has to assume not only its ascribed positions imposed with the name but also this unsymbolizable domain nevertheless "dwelling" in its psychic life ${ }^{24}$. The hegelian-lacanian motto that "the symbol kills the thing" is to be understood as operative only on the paradoxical condition that the Thing is created as such precisely by the fact that, excluded from the level of discourse, it always remains as phantasm. This means that, prior to the impossibilities frequently imposed by heteronormativity, to grief certain types of lost objects, there is already a trouble in the fact that I'm helplessly melancholic.

And this leads us to recognize, precisely because of this priority, the urgency in dislodge the discussion of a given truth or adequate socialization of the subject from the domain of society's communication. In order to acknowledge the complexity involved in formation of a gender identity is possible to see mechanisms of accommodation and "deflection" of the subject's identification with the cultural dominant standards (stereotypes). But at a theoretical level we must concede that Society no longer needs a strict reference to the remnants of nature in order to justify its own reproduction and so assure the difference between genders. If Hegel was conscious of this autonomy of social communication patented

${ }^{23}$ In Giving an Account of Oneself, where Butler expands her latest interest in the individual and collective narrative accounts and the effects of memory, she refers that: «Lacan has made clear that whatever account is given about the primary inaugural moments of a subject is belated and phantasmatic (...) The origin is made available only retroactively, and through the screen of fantasy.» (2005: 52-3).

24 A condition that reminds the notion of "extimacy (extimité) developed by Lacan, a strange element (Thing) present in the subject as an interior-exterior constitutive of its field of meaning. Cf. e.g. 1992: 71 ff, 139 ff, and chapter XVI of Seminar XI (1973). 
in a semantic already evolving to reconstruct passion (clearly distinct of his own concept of Liebe) as criteria to family forms, Lacan's concept of symbolic, in its relative autonomy, will reinvent a Freudian discourse that remained in various points attached to a biological grounding, early diagnosing the decline of the paternal imago (cf. Lacan, 1938: 166-168 and Roudinesco, 1993: 146-148)

In spite of the inarguable merit of the purpose to understand identity as a virtual/temporal process of becoming in which take part various factors gathered in an (apparent) simplicity of the individual, it may be that Foucault's influence prevents Butler to acknowledge how modern society cannot be taken exclusively as a net of power-knowledge discourses affronting the individual self-determination. In fact, only in this society, capable in its self-description to discover itself as malaise, have become possible to enjoy our symptom(s) and even obey Lacan's injunction: «do not cede upon your desire» (Lacan, 1997: 321).

\section{CONDENSED BIBLIOGRAPHY}

BUTLER, J., Subjects of desire: Hegelian reflections in twentieth--century France. reed., New York: Columbia University Press, 1987/1999.

BUTLER, J., Gender trouble: Feminism and the subversion of identity. reed., New York \& London: Routledge, 1990/199.

BUTLER, J., Bodies that matter: On the discursive limits of "sex." New York and London: Routledge, 1993.

BUTLER, J., The psychic life of power: Theories of subjection. Stanford: Stanford University Press, 1997.

BUTLER, J., Antigone's claim: kinship between life and death. New York: Columbia University Press, 2000.

BUTLER, J., "Restaging the Universal: Hegemony and the Limits of Formalism" in Contingency, Hegemony, Universality: Contemporary dialogues on the left, $2000 \mathrm{a}$.

BUTLER, J., "Competing Universalities" in Contingency, Hegemony, Universality. Contingency, hegemony, universality: Contemporary dialogues on the left, $2000 \mathrm{~b}$.

BUTLER, J., Giving an Account of Oneself. New York: Fordham University Press, 2005.

BUTLER et al., Contingency, Hegemony, Universality: Contemporary dialogues on the left. London \& New York: Verso, 2000.

FINK, B., The Lacanian Subject. Between Language and Jouissance, New Jersey: Princeton Universities Press, 1995. 
FREUD, S., "Mourning and melancholia" in ID. Standard Edition (1953-1974), ed. J. Strachey et al., London: The Hogart Press and the Institute of Psychoanalysis, vol. 14: 237-258, 1917.

FREUD, S., "The ego and the id" in SE, 19: 1-66, 1923.

FREUD, S., [1929], Civilization and its discontents, New York: W. W. Norton. JURANVILLE, A. (1984), Lacan et la Philosophie, Paris: PUF, 1962.

KOJÈVE, A., [1933-39], Introduction a la lecture de Hegel. Leçons sur la Phénoménologie de L'Esprit (ed. R. Queneau), Paris: Gallimard, 1947.

LACAN, J., "La famille: le complexe, facteur concret de la psychologie familiale. Les complexes familiaux en pathologie" (166-68) in Tout Pas-tout Lacan (available at http://www.ecole-lacanienne.net/bibliotheque.php?id=10). Lacan, J. (1966) Écrits. Paris: Seuil, 1938.

LACAN, J. (1966 b) [1960], "Subversion du sujet et dialectique du désir dans l'inconscient freudien", in ID., Écrits II (1966). Paris: Seuil.

Lacan, J., [1964], Le Séminaire, Livre XI, Les Quatre Concepts Fondamentaux de la Psychanalyse, Paris: Seuil, 1973.

LACAN, J. [1969-70], Le Séminaire, livre XVII, L'envers de la psychanalyse, Paris: Seuil, 1991.

Lacan J., [1959-60], The Seminar of Jacques Lacan, Book VII, The Ethics of Psychoanalysis, ed. Jacques-Alain Miller, New York: W. W. Norton, 1992.

Lévi-Strauss, C., «L'Efficacité Symbolique» in ID. (1974) Anthropologie Structurale, reed., Paris: Plon, 1949.

HEGEL, G. W. F. Phänomenologie des Geistes, Hamburg: Felix Meiner Verlag, 1988.

HEGEL, G. W. F. Grundlinien der Philosophie des Rechts, Hauptwerke in sechs Bänden, Band 5, Hamburg: Felix Meiner Verlag, 1999).

HEGEL, G. W. F., Enzyclopädie der Philosophischen Wissenschaften im Grundrisse, Hauptwerke in sechs Bänden, Band 6, Hamburg: Felix Meiner Verlag, 1999.

NANCY, J-L., [1997], Hegel. The restlessness of the negative, Minneapolis / London: University of Minnesota Press, 2002.

ROUDINESCO, E., Jacques Lacan. Esquisse d'une vie, histoire d'un système de pensée, Paris: Fayard, 1993.

WERNER, L. The Restless Love of Thinking: The Concept Liebe in Hegel's Philosophy, Helsinki: Helsinki University Press, 2007.

ŽIŽEK, S., Tarrying with the negative: Kant, Hegel, and the critique of Ideology, Durham: Duke University Press, 1993. 